\title{
THE NORTHERN LADOGA REGION AS A PROSPECTIVE TOURIST DESTINATION IN THE RUSSIAN-FINNISH BORDERLAND: HISTORICAL, CULTURAL, ECOLOGICAL AND ECONOMIC ASPECTS
}

\author{
Svetlana V. Stepanova \\ Institute of Economics \\ Karelian Research Center of the Russian Academy of Sciences \\ 50 A. Nevskogo st., Petrozavodsk 185030, Republic of Karelia: Russia \\ e-mail: svkorka@mail.ru
}

\begin{abstract}
The work reported here has examined the transformation of the Northern Ladoga region (a natural and historical region in the Russian-Finnish borderland) from 'closed' border area into a prospective tourist destination in the face of changes taking place in the 1990s. Three periods to the development of tourism in the region are identified, while the article goes on to explore general trends and features characterising the development of a tourist destination, with the focus on tourist infrastructure, the developing types of tourism and tourismoriented projects. Measures to further stimulate tourism as an economic activity of the region are suggested.
\end{abstract}

\section{Key words}

tourism development - the Northern Ladoga region - tourist destination - Russian-Finnish borderland - Republic of Karelia - political and socio-economic changes

\section{Introduction}

This paper examines tourist and recreational development taking place in the Northern Ladoga region ("the region") of the RussianFinnish borderland. In particular, the transformation of the region from 'closed' border area into a prospective tourist destination of the Republic of Karelia (Russia) is addressed, in the light of the impact of political and socioeconomic changes taking place in the 1990s.
The region was chosen for its geographical and historical retrospectivity, its attractive natural and cultural resources and developing tourist infrastructure and its services dealing with increasing numbers of visitors. One of the major factors behind the development of tourism in the region throughout history has been attractiveness to tourists on the one hand and a border location on the other.

The several distinct parts of this paper focus, first on the uniqueness of the Northern 
Ladoga region and on prerequisites for the development of tourism and recreation, and, second on the three identified periods to the development of tourism in the region. Influences of changes in the state on the creation of a new tourist place in the Russian-Finnish borderland are also investigated. A third part then concentrates on general trends and features of the development of the tourism destination, with a focus on tourism infrastructure, on the development of types of tourism, as well as on tourism-oriented projects. Finally, attention is paid to understanding the significant changes taking place in the Russian-Finnish borderland, and offering measures by which tourism as an economic activity may be stimulated.

\section{Literature review}

Border regions constitute peripheries and are often considered disadvantaged economically. However, borderlands also tend to feature unique historical and cultural potential and natural landscapes (Więckowski 2010). Since the 1990s, in the circumstances of remarkable geopolitical transformations "border studies have become a prominent research topic in several academic disciplines" (Timothy et al. 2016). The growing role of tourism within borderland areas that has significant implications for local and regional development has led to an increase in numbers of studies in this field.

Discussions concerning the significance of a political border as regards the functioning of tourism and cross-border cooperation in tourism have increased in number in the last three decades. A three-fold typology for the spatial relationships pertaining between a border and tourism was suggested by J. Matznetter (1979), while the theoretical foundations of the subject seen from various perspectives were established by D.J. Timothy (2001). Timothy and colleagues (2016) presented an overview of border tourism theory and examined "some of the traditional relations between borders and tourism". "The appearance and disappearance of borders" accompanied by their "openings and closings that are expressed through changes in their functions" have important implications for tourism and recreational development (Więckowski \& Ceric 2016), and for the local economies as a whole. Geographical position opens up an extra opportunity for cross-border cooperation, as well as for competitiveness of tourist destinations in a borderland to be enhanced (Vodeb 2010; Więckowski et al. 2014; Bujdoso et al. 2015). Challenges facing the development of new places for tourism in border area and in cross-border tourist space have been discussed in broad terms by researchers (Prokkola 2008, 2010; Nilson et al. 2010; Więckowski \& Cerić 2016). The influence of cross-border tourist routes on a local economy have in turn been investigated in European border regions in particular, including in the regions bordering with Russia (Kovács \& Nagy 2013; Kropinova 2014). Special attention has also been paid to tourism and crossborder mobility as important factors underpinning a borderland's development (Więckowski 2010; Makkonen 2016). Some studies have had a general focus on marketing and on destination competitiveness of a borderland, on the basis of a sociological approach taken (Vodeb $\&$ Nemec Rudež 2017). Along with an increasing role of tourism in a local economy (Saarinen 2003), the significance of studies that assess the sustainability of tourist systems, with an emphasis on the defining of limits to the growth of tourism, has increased (Saarinen 2014a, 2014b; Nyaupane et al. 2018).

Since the early 1990s, the socio-economic transformation and changes in the geopolitical situation of Russia on the world stage have served as an impetus for research on the regional development of the Russian Federation. For the first time the scientific community initiated broad discussion on new opportunities - as well as new challenges - relating to the development of Russia's border regions, as well as on prospects for crossborder cooperation and areas of development. Given that, for many years, the border areas of the Soviet Union were closed even to the state's own population, the dominant 
'locked-down border' ideology (Artobolevskij 2006) had a retarding effect on regional development. However, in favourable new geopolitical and institutional conditions, the contact function of the state border of Russia began to dominate for the first time in recent decades (Mezhevich 2006).

Since the 1990s, growing academic attention paid to border regions has also increased study of the Russian-Finnish borderland. On the one hand, the Republic of Karelia has been started to learn as a border periphery region in the Northwest Russia (Eskelinen et al. 1994; Shlyamin 2002; Druzhinin 2005). On the other hand, the research area of the Russian-Finnish borderland - "the area known as Karelia in particular" (Scott 2012), is shared regional space. Cross-border mobility and its influence on the landscape as regards Finnish tourism have been revealed in some research (Jakosuo 2011; Laine 2017).

Discussions on Russia's border regions and the opportunities for tourism to develop in them have followed on from transformational changes and have led to an upsurge of research among Russian scholars, revealing the current situation, specific features and efficiency of the tourism industry present in the borderland. For the first time, tourism has become a research topic related to the development of the Republic of Karelia (Gromov 2003; Saveljev \& Tolstoguzov 2008; Izotov \& Laine 2013; Stepanova 2016; Laine 2017), in this way supplementing the vision for that area's industrial development. A number of studies concern themselves with cross-border cooperation (Morozova 2006; Shekov 2015; Makkonen et al. 2018) and tourism development, with the typical focus being on the development of the relevant infrastructure (Saveljev \& Tolstoguzov 2008; Shishkin \& Petrova 2013) as a key factor if better business in tourism is to be done.

However, the studies alluded to have mostly concentrated on selected types of tourism, and presented data for the Republic of Karelia as a whole, rather than just its borderland areas. However, thanks to its unique heritage and borderland location, the Northern
Ladoga region has become an area with prospects where the development of tourism in the Republic of Karelia is concerned. One strand to that is nature-based tourism, which is thus predicated on the conservation and reproduction of the natural resources in the Northern Ladoga region as prominent directions of study (Mikhailova et al. 2000; Ivanter et al. 2012; Sevastjyanov et al. 2014). The opportunity to involve the territory's mining and geological heritage in tourism has been investigated in certain papers (Artemyev \& Yushko 2012; Shekov 2015; Nenonen \& Stepanova 2018), while several studies have focused on selected aspects of tourism development in the region over particular time periods (Potakhin 2001; Pashkov 2004; Stepanova 2012; Izotov \& Laine 2013). Study based on a sociological survey has allowed for comparison of the rural areas of the Republic of Karelia and of Finland where tourism development is concerned - in the view of customers (Karhapää-Puhakka \& Suni 2014).

In spite of the scientific interest, research into tourism development in the Northern Ladoga region is limited to a small number of studies devoted to opportunities for the development of nature-based tourism, mostly in the context of international projects, as well as certain historical aspects. Accumulated research capacity is not therefore adequate to allow for a full understanding of the transformation taking place in the borderland. The study tries to answer a question as to how socio-economic transformations taking place in Russia since the early 1990s have influenced the development of the Northern Ladoga region from being a 'closed' border area into a role as a new destination for tourism in the Russian-Finnish borderland.

\section{The Northern Ladoga region as a research area}

The Northern Ladoga region is considered a prospective tourism destination of the Republic of Karelia (the Republic) located in the Russian-Finnish borderland. The Republic is located in NW Russia, while its western 
boundary (of $798 \mathrm{~km}$.) coincides with the state border of the Russian Federation and Finland (Kurilo et al. 2009; Unified ... 2018).

The Northern Ladoga region ("Severnoe Priladozhje" in Russian) is a natural and historical region bordered by the shore of Lake Ladoga, the administrative boundary of the Leningrad region and the Republic of Karelia, the Russian-Finnish state border, and the conventional line followed by the old (1939) Soviet-Finnish border in the east (Severnoe Priladozhje). The region thus comprises three municipalities in the south-western part of the Republic of Karelia, i.e. Sortavala, Pitkyaranta and Lahdenpohja (Fig. 1.).

With a total area of $6,655 \mathrm{~km}^{2}$, some $3.7 \%$ of the territory of the Republic is accounted for here. The population is in turn of 61,700 people (as of 1 January 2018); with $68.2 \%$ living in cities or other urban-type communities). This is $9.9 \%$ of the population of the Republic as a whole (The Federal target).

The Northern Ladoga region has an international border crossing point of Vyartsilya-Niirala (Sortavala District), as well as a temporary border crossing point at Syväoro-Parikkala (Lahdenpohja District), which has some limitations on crossings by passengers. Another precondition underpinning the development of tourism is an international tourist route called the Blue Highway connecting the Republic of Karelia with Scandinavian countries; as well as the road connecting St. Petersburg with

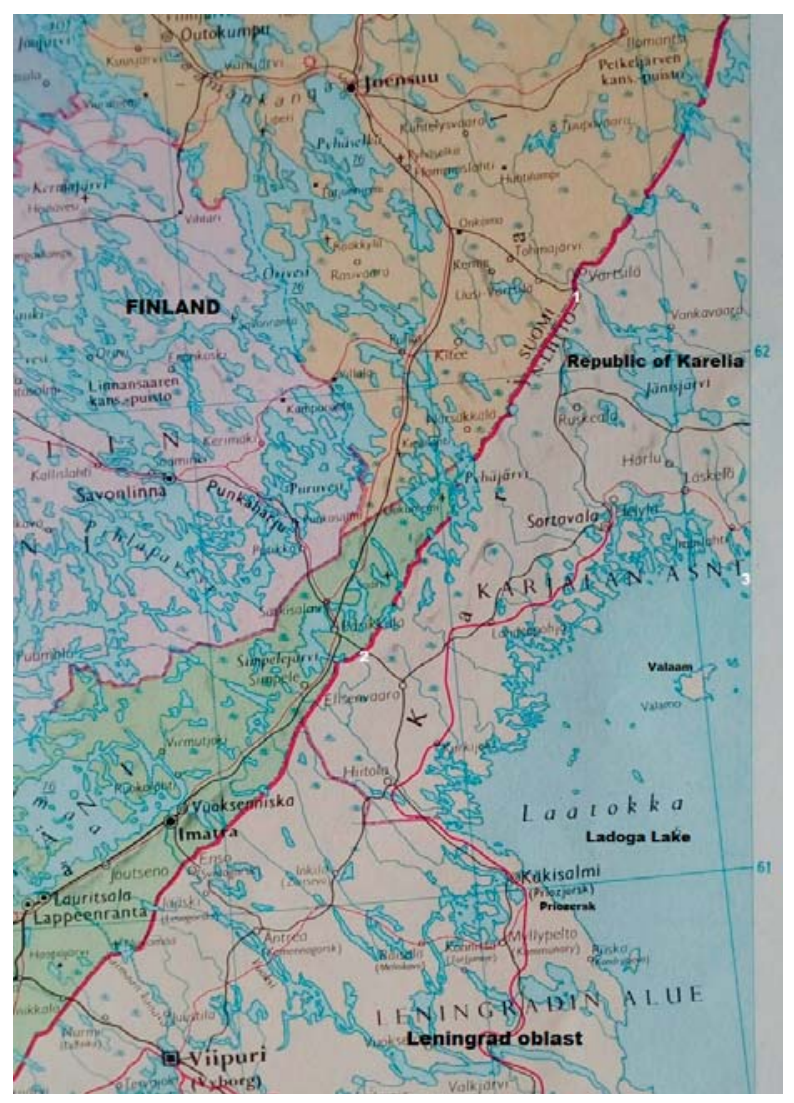

Figure 1. The Northern Ladoga region with marked numbers ( 1 - the international border crossing point Vyartsilya-Niirala; 2 - the temporary border crossing point Syväoro-Parikkala; 3 - Pitkyaranta city)

Source: Based on Tammen Maailmankartasto (1987). 
Petrozavodsk (the capital of the Republic), which also passes through the region.

Lake Ladoga is Europe's largest (at $17,890 \mathrm{~km}^{2}, 219 \mathrm{~km}$ in length and up to $112 \mathrm{~km}$ in width, as well as a maximum depth of $230 \mathrm{~m}$ ), and it features picturesque skerries in its northern part. Ladoga hosts over 600 islands, while 70 rivers flow into the Lake, and the water is renewed every 11 years. There is the Ladoga seal - a small sea mammal, which is a relic of the glacial epoch included in the Red Books of Russia and on the Red List of Threatened Species. The Lake supports 58 species of fish, including the endangered Ladoga salmon (Mikhailova et al. 2000; Ivanter et al. 2002; Kurilo et al. 2009; Unified... 2018). The presence of protected areas of various kinds is a basic component of tourism development in the region. Most of these are associated in some way with Lake Ladoga (Specially protected ... 2017): the Valaam archipelago (nature park), "Sortavalskiy" Reserve (in Sortavala District), as well as the "Western archipelago" (in Lahdenpohja District). In addition, 28 December 2017 brought the establishment of the Ladoga Skerries National Park by Decree of the Government of the Russian Federation (Russian Federation ... 2017). Several cascades of waterfalls located close to the Blue Highway have become popular tourist sites of the region in recent years (examples might be the White Bridge $(18 \mathrm{~m})$ and the $(6 \mathrm{~m})$ Koirinoja Falls in Pitkyaranta District, as well as the Ruskeala Falls in Sortavala District) (Karelia 2012).

The shore of Lake Ladoga became inhabited after the last Ice Age, as soon as the edge of the ice sheet retreated northward. The oldest settlements are concentrated in the areas of Kurkijoki and Hiitola (now in Lahdenpohja District). Over the centuries, the region has been under the rule of Novgorod (Russia), Sweden, Russia, Finland, the Soviet Union and Russia again. In 1617, immediately after the Treaty of Stolbovo was signed, the territory was detached from Russia to profit from the dominance of Sweden. It was then in the middle of the 17 th century that the settlement of Sordwalla was established (otherwise Serdobol and the present-day Sortavala), while there were also other Swedish settlements of Salmis (Salmi, in Pitkyaranta District), and of Kronoborg (Kurkijoki, in Lahdenpohja District). After the Great Northern War (17001721), the territory was joined to the newlyestablished Grand Duchy of Finland, within Russia, and it remained a part of the newlyindependent Finland in 1917. The Moscow Peace Treaty, which ended the Winter War (12 March 1940), dictated that the territory be ceded to the Soviet Union (Pashkov 2004; Izotov \& Laine 2013).

The area of the Northern Ladoga region has more than 740 state-listed monuments, or $40 \%$ of the total for the entire Republic. Sortavala District ranks first in the Republic in terms of the number of state-registered architectural monuments (487 objects or $29.1 \%$ ). The most attractive and popular objects in the region are located in Sortavala District. First, there is the Valaam archipelago (nature protected area) located in the north-western part of Ladoga Lake, along with the natural and architectural complex of the ancient Holy-Transfiguration Valaam Monastery. The first period of foundation of this Orthodox Monastery was the late 10th and early 11th centuries, or the first half of the 14th century. The main stone building of the Monastery is the Holy Transfiguration Cathedral (70 m), which was built in the late 19th century (Karelia 2012). Secondly, the town of Sortavala has the status of historical town of Russia due to its unique architecture: about 90 buildings there are of cultural and historical value. A unique museum on the scale of the whole Republic is the Museum of wood carvings made by People's Artist of Russia Kronid Gogolev (Karelia 2012; Unified... 2016c). A first for Russia and a feature unique on the European scale is the Ruskeala Mountain Park - as a new tourist attraction of the Republic of Karelia created from an old (late 17th-century) marble quarry at the end of the 1990s. The marble was used in the decoration of architectural masterpieces in St. Petersburg, such as St. Isaak's 
Cathedral. Today, the marble canyon is a key aspect of the Ruskeala Park (450 m in length, about $100 \mathrm{~m}$ wide and $50 \mathrm{~m}$ deep) (Artemyev \& Yushko 2012; Karelia 2012; Ruskeala Mountain). Half (48.9\%) of the state-listed monuments of Lahdenpohja District are archaeological monuments, while more than a third $(36.7 \%)$ are architectural (Objects of cultural...; Unified... 2016a). A new warhistorical object called "Owl Mountain" and enjoying a cliff location was established as part of the effort to create a tourist and recreational cluster in South Karelia. It came into being several years ago in Lahdenpohja District. The natural grotto was used in the years 1943-4 as Finnish Army battle headquarters. In total, Pitkyaranta District has 108 monuments: over half (58.3\%) of these relate to the Winter War and Great Patriotic War, while $25 \%$ are monuments of architecture, and $11 \%$ monuments of archeology. There is a memorial zone in the Valley of Heroes relating to the tragic events of the Winter War (1939-1940), while the historical Nietjarvi memorial is what represented a section of the Mannerheim Line located in the Pitkyaranta District. The most ancient monument is the Varashaev Stone - a rare specimen of a border marker (from 1618), denoting the old national border between Russia and Sweden (Objects of cultural...; Karelia 2012; Unified... 2016b).

\section{Tourist and recreational development in the Northern Ladoga region: historical aspects}

Political and socio-economic changes through history have influenced greatly both the transformations taking place in the RussianFinnish borderland and the opportunities made available for tourist space and places in the region to be established. Major factors in this process of development have been the unique natural, historical and cultural heritage, as well as the borderland location. More specifically, however, it proves possible to identify several key periods in the development of tourism here (Fig. 2):

- the "Finnish period" (19th and early 20th centuries);

- tourism as a sphere of social activity in the USSR (1960s-1990s);

- tourism as a business in the market-economy context (1990s onwards).

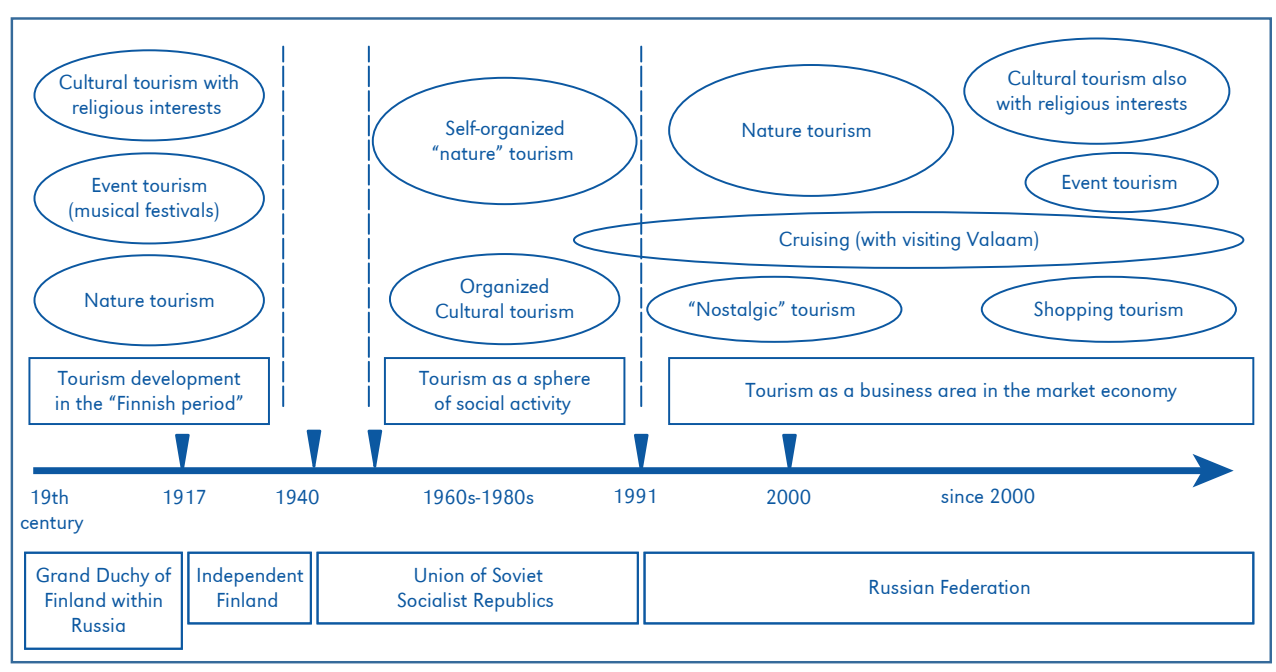

Figure 2. The development of tourism in the Northern Ladoga region - major types of tourism 
Traits selected as allowing a distinction to be drawn between these periods are form of government, level of development of transport infrastructure, the role of tourism in the local economy, the level of development of infrastructure specific to tourism and the volume describing the influx of tourists.

Period 1 was a time at which this region's first infrastructure specific to tourism was in the process of being built actively. Such development was ongoing until 1940 - first on the territory of the newly-established Grand Duchy of Finland (within Russia) and, post-1917, in the independent Finland (Stepanova 2012). Publication of the KarelianFinnish epic "Kalevala" relating to events on the both sides of the present border (Scott 2012) accounted for the growing popularity of tourist routes across runo-singing districts. In 1877, a (Finnish) 500-mark banknote was issued, which depicted Lake Ladoga as seen from Riekkalansaari Island (Potakhin 2001). Then, in 1895, the Finnish Tourism Association published a detailed "Guide to Finland", whose biggest section (of 56 pages) was given over to tourism routes and accommodation facilities in the region under study here. The hub for tourism at that time was Serdobol, where large singing festivals have been organised since 1896. Tourism development was naturally much influenced by the construction in the 1890s of a railway connecting Vyborg to Serdobol (1893) and Joensuu (1894). The latter locality is today the capital of (Finnish) North Karelia. It was the stretch of railway across Hiitola (in Lahdenpohja District) that maintained the most vigorous traffic, given the way it facilitated development of pioneering nature tourism. However, through to 1917 , the major tourist destination in this whole region was Valaam Orthodox Monastery (Potakhin 2001; Saveljev \& Tolstoguzov 2008).

It was in December 1917 that Finland gained its independence, with Serdobol then renamed Sortavala. The 1930s brought a quite active development of bus connections in the region, and the high standard of services available for cars promoted the development of motor tourism. While both railway and road connections did indeed develop, Lake Ladoga itself remained an essential transport route, with the main passenger port in Sortavala and the best port in Lahdenpohja (regular connections ran from both ports to Valaam Island). The schedules for steamboats and for trains arriving from the south were harmonised, while regular Lahdenpohja-Kurkijoki, Sortavala-Impilahti, Sortavala-Pitkyaranta, Sortavala-Salmi, etc. water routes were also offered to passengers (Potakhin 2001; Stepanova 2012). Itineraries were of both a local nature (involving excursions and tours over several days) or of longer duration: local bus/auto routes (9.8-41.7 km.) with visits to Sortavala, Lahdenpohja, Ruskeala, etc. There were also local steamboat routes for tourists (2-12 hours in duration), taking in the Ladoga skerries and Valaam archipelago; and a joint water-bus-walking route (for several days), also from Helsinki and Turku. For the most part, accommodation facilities in this region took the form of small hotels and guest houses. Major tourist objects were located in Sortavala, Lahdenpohja and surrounding areas (Lintunen et al. 1998; Saveljev \& Tolstoguzov 2008). Cultural tourism with a religious slant, nature tourism and event tourism (visiting the aforementioned song festivals) were the major types. European guidebooks pictured the northern shore of Lake Ladoga as a most marvellous land second only to the Swiss Alps (Potakhin 2001; Saveljev \& Tolstoguzov 2008).

The Soviet era brought a dramaticallychanged perception of tourism and its role in local development. Traditionally, neither the authorities nor locals back in the period of the 1960s-1990s recognised tourism as an efficient (i.e. income-generating) sphere of economic activity. The primary reason for that was the concept of tourism as a social activity and way of promoting health. On the other hand, tourism was mostly a social matter in the USSR (being state-subsidised), though nature tourism was largely selforganising and involved camping, fishing, gathering the berries and mushrooms, taking 
water routes, etc.). As a background, the distribution of income across the country was of a centralised nature (Stepanova 2012). Unlike in earlier and later times, Soviet-era cultural tourism was something taking place with no account taken of religion. "Tourism was highly politicized" (Laine 2017). Travels of foreign citizens to and within the Soviet Union were in turn organised by Intourist, as the official state travel agency. Intourist was responsible for managing and serving that inbound tourist flow into the USSR (also that involving Finns). Some trips were organised via the Finnish-Soviet Union Society, in the context of furthered Soviet-Finnish relations (Izotov \& Laine 2013). Besides, in Soviet times, a state border with a capitalist state (even one such as Finland) by definition denoted a dividing line (and hence a further stretch of the "Iron Curtain"). That also meant a barrier function where movements of goods and money were concerned, as well as human beings of course, and even cultural influences. The dominant 'locked-down border' ideology (Artobolevskij 2006) had a retarding effect on regional development. According to P.V. Druzhinin (2005), a borderland location meant numerous military facilities on the one hand, but weak development of transport infrastructure and limited economic activity on the other. Access to border territories was anyway restricted, with entry only possible once various special documents had been obtained (i.e. a travel permit relating to work trips, an invitation to visit friends and relatives, or an itinerary document confirming participation in an organised tourist group).

It was nonetheless during the Soviet period that an image of a 'tourist Karelia' of unique natural and cultural potential gradually came to be shaped in the minds of many citizens of the USSR. Thus, when Petrozavodsk-Kizhi-Valaam-Leningrad route was launched in the 1980s, the number of tourists reaching the Karelian Autonomous Republic rose to 800,000 a year (Stepanova 2012). Half of the twelve tourist routes in the Republic elaborated by the Karelian Oblast
Council in the interests of tourism and excursions entailed summer-only water routes that took in visits to the Valaam Archipelago (Saveljev \& Tolstoguzov 2008). In 1980 more than 11,000 people visited Sortavala and adjacent areas, while in the mid-1980s visitor numbers reached 12,000 (Potakhin 2001). Yet, despite a certain development of tourism in consequence, the effect on the region's socio-economic development remained insignificant, and indeed the economic dimension to tourism was neglected rather studiously.

The collapse of the Soviet Union and attendant transformation from a planned to a market economy has played its crucial role in the development of tourism in the region under study. The opening-up of 'closed' border regions and of international border crossing points combined with visa-regime simplification to generate tourist influxes from Finland, with private enterprise in the region also promoted as a consequence. The first positive effect of tourism on the local economy was the rise of so-called 'nostalgia tourism', whereby Finns have the opportunity to visit the Northern Ladoga region (Gromov 2003; Stepanova 2012; Izotov \& Laine 2013). This was then a period of the 'rediscovery of Karelia', with a boom of such nostalgic journeys to the Republic taking place (Eskelinen et al. 1994). Sortavala was a major destination for Finnish travellers in the region. For instance, the distance from Sortavala to Joensuu is about $120 \mathrm{~km}$ (Fig. 1). The number of Finnish tourists coming to the Republic increased to 700,000 a year, and around 100 private tourist companies appeared (Gromov 2003; Stepanova 2012). Thus, the economic-geographical location (of a borderland character) was gaining in significance and beginning to act as a new factor in regional socioeconomic development. Tourism then began to take shape as a sector of the local economy generating income for the budget and creating new jobs. The 1990s were thus the watershed for tourism development as a new business.

The uncontrolled boost to tourism brought to light certain challenges where further 
development was concerned, including underdeveloped infrastructure, a low standard of services, a lack of qualified specialists, the absence of a strategy for the development of tourism and so on. Tourist influxes from Finland have been the subject of dramatic change, with just 150,000 a year coming over in the mid-1990s (Gromov 2003). However, the spontaneous development of 'nostalgia' tourism made clear the role and potential benefits of tourism where the region's socio-economic development is concerned. To maintain rates of development of tourism and enhance efficiency in the wider context of the Republic's economy, tourism for the first time began to be highlighted as a development priority, thereby gaining inclusion in the main strategic document known as the "Concept of social-economic development of the Republic of Karelia for the period 1999-2002-2010" (The main provisions...; Stepanova 2016). Strategic planning in relation to the destination "is to ensure solutions with synergistic effects" (Vodeb 2010). Today, the Republic of Karelia has an established and constantly improving system of strategic management, which extends to both strategies for tourism and regional development programmes.

\section{General trends and features of tourism development in the Northern Ladoga region}

Tourism infrastructure obviously represents one key condition for the successful operation of a tourism business, with a wide range of competitive tourism services provided, and use made of the tourist and recreational potential of the territory without the environment coming to be damaged. Research reveals that the Northern Ladoga region has a high level of development of accommodation infrastructure (Tab. 1).

Almost a quarter $(24.3 \%)$ of the accommodation facilities of the Republic of Karelia are located in the Northern Ladoga region. Their distribution is very much predetermined by the unique nature of the Lake Ladoga shoreline. Guest houses and cottages with leisure bases are the largest of types of accommodation facilities (accounting for about $60 \%$ of the total). On the one hand, self-organised tourists choose to take a rest in natural areas dominated by nature-based activities (fishing, hunting, etc.), and on the other, guest houses and cottages require less investment prior to business starting up. Russian owners adopt practices from the Finnish tourism business. There are territorial imbalances when it comes to the location of tourist infrastructure in the region. The greater part of this region's accommodation infrastructure $(60.9 \%$ of accommodation facilities, $59.2 \%$ of places available) is located in Sortavala District. With an integral indicator equal to 3.11, the latter ranks first among the municipalities of the Republic (after Petrozavodsk), where the level of tourism infrastructure development is concerned. Pitkyaranta District has the lowest level of development of tourist infrastructure in the region, thanks to the city's industrial history, and a geographical position leaving it located at some distance from the international tourist route known as the Blue Road. At the same time, provisioning with tourism infrastructure characteristic for different municipalities (as in Tab. 2) is seen to be strong in Pitkyaranta District.

Most tourist infrastructure in this region has been put in place over just the last two decades. Today, the Northern Ladoga region is one of the areas inclined to attract investments in tourism infrastructure in the Republic of Karelia. The tourism and recreation cluster of South Karelia (including the region and two other municipalities of the Republic) is considered a tool by which to generate competitive tourism products, as well as tourist services of greater quality. For example, by 2025 , a total of more than 5 billion rubles will have been invested in the South Karelia tourism and recreation cluster. Through the further development of tourism, it is envisaged that there will be a 250,000-person increase in the total annual influx of tourists into the Republic of Karelia (Karelia will). 
Table 1. The level of development of municipal tourism infrastructure in the region (on 1 January 2018)

\begin{tabular}{|c|c|c|c|c|}
\hline \multirow[b]{2}{*}{ No. } & \multirow{2}{*}{$\begin{array}{c}\text { The municipalities } \\
\text { of the region }\end{array}$} & \multicolumn{3}{|c|}{$\begin{array}{l}\text { Indicators of development } \\
\text { of the structural element to tourist infrastructure }\end{array}$} \\
\hline & & $\begin{array}{l}\text { accommodation } \\
\text { infrastructure }\end{array}$ & $\begin{array}{c}\text { food } \\
\text { infrastructure }\end{array}$ & $\begin{array}{c}\text { leisure } \\
\text { and recreational } \\
\text { infrastructure }\end{array}$ \\
\hline 1. & Sortavala District & 4.97 & 2.06 & 2.3 \\
\hline 2. & Lahdenpohja District & 2.12 & 0.49 & 2 \\
\hline 3. & Pitkyaranta District & 1.14 & 0.91 & 0.57 \\
\hline 4. & $\begin{array}{l}\text { median indicator for the Republic } \\
\text { of Karelia }\end{array}$ & 1 & 1 & 1 \\
\hline
\end{tabular}

Source: * author's calculation. The research is based on data from the official websites of the administrations of the three municipalities in the region, the official portal of the Tourist Information Centre of the Republic of Karelia, the booking system for hotels at booking.com, the TripAdvisor travel website, as well as unified tourist passports of the three municipalities of the region and of the Republic of Karelia.

Calculation based on author's methodological approach to assessing the level of development of municipal tourist infrastructure (Stepanova \& Shulepov 2019), where:

\begin{tabular}{|c|c|c|}
\hline No. & Calculation formula & Explanations \\
\hline 1. & $I_{d j}=\frac{F_{d j}}{m j}$ & $\begin{array}{l}i_{d j} \text { - index of the } j \text {-th indicator of the } d \text {-th Republic's municipality } \\
F_{d j} \text { - actual } j \text {-t indicator of the } d \text {-th Republic's municipality } \\
m_{j} \text { - median of the } j \text {-th indicator of the Republic's municipality }\end{array}$ \\
\hline 2. & $I_{d k}=\frac{1}{x} \sum_{j=1}^{x} i_{d j}$ & $\begin{array}{l}I_{d k}-\text { indicator of development of the k-th structural element of tourism } \\
\text { infrastructure of the } d \text {-th Republic's municipality } \\
x-\text { number of selected indicators of the structural element to tourist } \\
\text { infrastructure }\end{array}$ \\
\hline 3. & $I_{d}=\frac{1}{n} \sum_{k=1}^{n} i_{d k}$ & $\begin{array}{l}I_{d} \text { - integral indicator of the level of development of tourist infrastructure } \\
\text { of the } d \text {-th Republic's municipality } \\
n \text { - number of structural elements to tourism infrastructure }\end{array}$ \\
\hline
\end{tabular}

Calculations make use of indices as follows: for accommodation infrastructure (numbers of hotels and similar accommodation facilities including number of sanatorium establishments as well as auto-camping (units) and numbers of places available in the facilities (units)); for food infrastructure (numbers of restaurants, cafes, bars (units) and numbers of places in restaurants, cafes and bars (units)); for leisure and recreation infrastructure (number of museums, exhibition halls, etc., numbers of active-tourism facilities such as yacht clubs, ski and horse-riding centres, water parks, etc. (units)).

"Accessibility is an important element for tourism development", also, it "plays a significant role in the choice of destination of a planned journey" (Więckowski 2014). In recent years, new roads have helped build up the new tourist attractions of the region: for instance reaching the Ruskeala Mountain Park within the Federal target Program "The development of domestic and inbound tourism in the Russian Federation during 2011-2018" (The Federal target ...), as well as the White Bridges waterfall. In December
2018, the OJSC Russian Railways connected St. Petersburg with Lahdenpohja, Sortavala and Ruskeala, using Lastochka high-speed trains to increase tourist influxes into the region (from St. Petersburg).

The other important indicator of tourism development in the region is the tourist flow. From the 2000s on, the number of tourists and visitors to the region increased 4.9-fold (Saveljev \& Tolstoguzov 2008; Unified 2016a, 2016b, 2016c; Nenonen \& Stepanova 2018). In 2017 the total inbound tourist flow to the 
Table 2. Provisioning of tourist infrastructure in the Northern Ladoga region, per 1000 people (as of 1 January 2018)

\begin{tabular}{|c|l|c|c|c|c|}
\hline \multirow{2}{*}{ No. } & \multicolumn{1}{|c|}{ Index } & \multicolumn{2}{|c|}{ Regional municipalities } & \multicolumn{2}{c|}{$\begin{array}{c}\text { Average for } \\
\text { Republic } \\
\text { of Karelia }\end{array}$} \\
\cline { 3 - 5 } & $\begin{array}{c}\text { Lahdenpohja } \\
\text { District }\end{array}$ & $\begin{array}{c}\text { Sortavala } \\
\text { District }\end{array}$ & $\begin{array}{c}\text { Pitkyaranta } \\
\text { District }\end{array}$ & 20.12 \\
\hline 1. & $\begin{array}{l}\text { Number of places available in hotels } \\
\text { and similar facilities providing } \\
\text { accommodation }\end{array}$ & 28.78 & 41.82 & 29.43 & 29.40 \\
\hline
\end{tabular}

Source: author's calculation. The research is based on data from the official websites of the administrations of the three municipalities in the region, the official portal of the Tourist Information Centre of the Republic of Karelia, the booking system for hotels at booking.com, the TripAdvisor travel website, as well as unified tourist passports of the three municipalities in the region and of the Republic of Karelia.

region was estimated at about 450,000 people; about half of all visitors were self-organising tourists (Unified 2016a, 2016b, 2016c; Nenonen \& Stepanova 2018). Tourist traffic is not distributed evenly across the region. The Sortavala District ranks first among municipalities of the region, in terms of numbers of visitors (2017 about 420,000 people). The Valaam archipelago and the Valaam monastery are annually visited about 120,000 tourists and pilgrims from all over the world (Unified 2016c). During the 20062017 period, the number of visitors to the Ruskeala Mountain Park (as a new tourist attraction) increased 42.9-fold (Fig. 3.).
Analysis of the dynamics of the tourist flow to Ruskeala over the study period reveals a stable upward trend $\left(R^{2}=0.96\right)$, suggesting it is turning into a developing business area. Thus, the tourist influxes in the Republic are now being reoriented towards more attractive destinations, and demand for unique, high-quality tourist products is growing. For instance, since 2015 the number of visitors to the Ruskeala Mountain Park has been exceeded by the number of visitors to Karelia's Kizhi - open-air museum of history, ethnography and wooden architecture (2017, about 180,000 peoples). This is located on Kizhi Island in Lake Onego. Importantly,

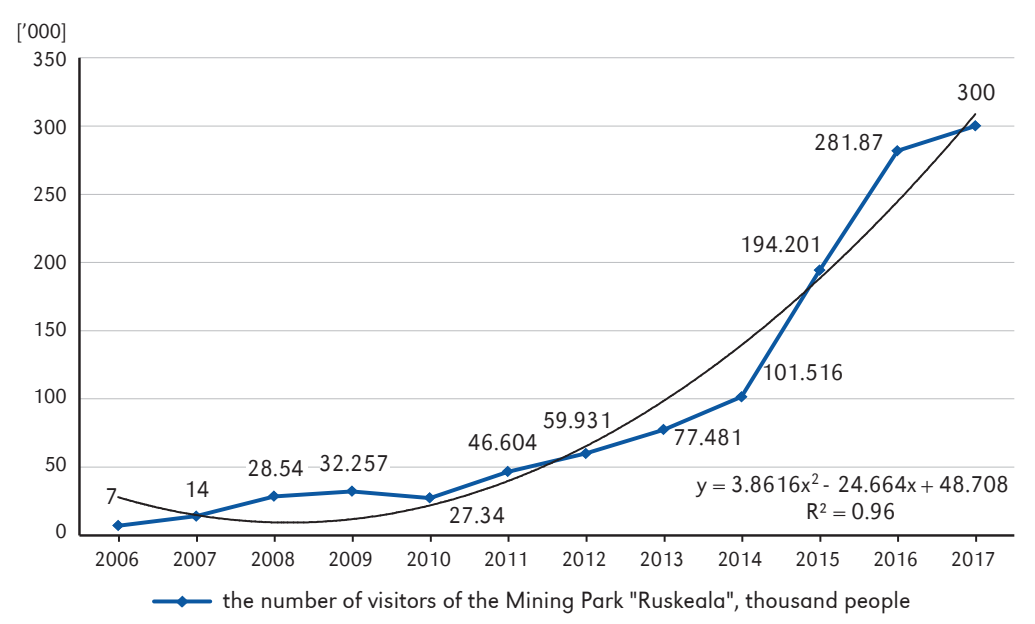

Figure 3. Numbers visiting Ruskeala Mountain Park (Nenonen \& Stepanova 2018; Ruskeala Mountain Park) 
the growing sizes of inbound tourist influxes create additional jobs in related spheres of the local economy, such as transport, catering, entertainments, as well as gift-manufacturing.

Certain features of the development of tourism in the Northern Ladoga region are revealed. Today, cultural tourism (also including religious interests), nature tourism, event tourism as well as shopping tourism (by Finnish travellers) represent major types of tourism here.

Cross-border tourism and the inflow of Finnish tourists into the region are considered important in terms of the further development of tourism and the local economy. The international border crossing of Vyartsilya-Niirala ranks first among those present along the Karelian part of the Russian-Finnish border, in terms of the level of cross-border traffic. In the 2012-2017 period it was on average crossed by $1,521,600$ people per year, or $73.9 \%$ on average of overall cross-border traffic along the Karelian part of the border (The Border Guard in figures). Along with opportunities for the region to be reached thanks to travel agencies or by private car, there is a daily international bus route running from Petrozavodsk to Joensuu, as an example of a cross-border initiative (Sortavala-Joensuu, about three hours' duration). Today, geographical proximity, price accessibility, the convenient working hours of the international border crossing point as well as of shops and restaurants are all important conditions motivating Finnish travellers to come to the region. According to I. Björn (2015), typical trips taken by Finns from North Karelia to the Republic of Karelia (motivated by the purchase of petrol) are of several hours' duration. However, three out of four Finns travelling in this way confine their visit to Vyartsilya. For example, the intensive cross-border traffic at the Vyartsilya-Niirala border-crossing point was a prerequisite for the existence of the small cafe at Kolmas (2 $\mathrm{km}$ further on) in the 1990s. Today, the main activities of Kolmas Karelia LLC are tourism, retail trade and catering. The high (90\%) share of Finnish tourists in the overall influx of tourists into the Republic from abroad in the 2005-2015 period just underlines a high level of dependence of the Karelian tourist industry on the dynamics of such flows from Finland. The challenge where the development of truly international tourism is concerned is also made clear.

In recent years, event tourism has become more and more attractive to Russian and foreign visitors coming into the region. Music festivals (at Valaam, Ruskeala, etc.) as well as different Rally competitions (Lahdenpohja and Sortavala Districts) prove to be the region's most popular events. Some of these have already developed their own history and tradition, while others only date back to the last few years. For instance, Rally White Nights is a stage of the Championship of Russia in motor sports and represents the oldest rally in Russia (run since 1963). The snowice rally has been held since 2003, and has in recent years become the first stage of the world's highest racing series Baja Russia - Northern Forest. These rally-raids take place under the auspices of the International Automobile Federation - the World Cup (Russia - Northern forest). In 2017, a Ruskeala Symphony Classical Music Festival was held for the first time in the Ruskeala Mountain Park, with 2,700 in attendance. In 2018, the figure exceeded 6,000 visitors (Ruskeala Symphony 2018; The second music 2018). In July 2018, more than 7,000 participated in the Fourth Orthodox Singing Festival held in Valaam.

Despite the presence of tourism resources allowing for year-round development, very marked seasonality of activity remains present in the region. Thus, tourist organisations are mostly active during the summer months, as well as in a short period surrounding New Year and Christmas.

The perception of a destination from a tourist's point of view is important for further development, and for the management process (Vodeb \& Nemec Rudež 2017). According to data from the Runat 
Project, in the 2010s some $39 \%$ of Russian respondents (mostly from Moscow, St. Petersburg, etc.) had no image (or knowledge) of the Ladoga Karelia destination. However, a high proportion (35\%) who had never travelled to the destination, would like to take a holiday there, while $10 \%$ of those who have been would like to do so again (Karhapää-Puhakka \& Suni 2014). The high share of respondents knowing nothing about the destination can be considered to reflect a lack of (successful) promotion of the region on the tourist-services market, as well as strong competition between destinations. At the same time, a third group of respondents demonstrate interest in visiting the destination. Thus, the development of tourism in the region is largely affected by the territory's transport accessibility, the current condition of infrastructure, the variety of tourism services available, and the image of the destination as well as the institutional conditions.

"Sustainability has emerged as a paradigm in tourism planning and development" (Saarinen 2014b) and "sustainable tourism is an ideal condition or end result of careful planning and responsible practices" (Nyaupane 2018). Limits to growth have become a key task in tourism development. "The evaluation and prediction of the growth and stimulation effects of tourism development are needed from the industry, public sector and local community perspectives in order to create jobs and well-being in peripheral areas" (Saarinen 2003). In 2006, the potential tourist capacity for the Northern Ladoga region was assessed at the 'magic number' of 550-600,000 people per year (The General Scheme... 2007; Saveljev \& Tolstoguzov 2008), in line with an activity-based tradition (Saarinen 2014a, 2014b). Despite rapid development of tourism in the region over the last three decades, this volume of tourist traffic has yet to be achieved. However, by 2025, the region's capacity for tourism might have been achieved or even overstepped due to additional growth in visitor numbers in line with the development of the South Karelia tourism and recreational cluster. The development of the Northern Ladoga region can be further activated through the development of infrastructure, as well as thanks to the introduction of new tourist products and activities (Saarinen 2014a, 2014b), the Ruskeala Mountain Park being an example.

In fact, over the past decade, the border location has driven the development of various tourism-oriented projects funded by the European Union, Finland and Russia (for instance, Mikhailova et al. 2000; Ivanter et al. 2002; Shekov 2015, etc.). These projects helped establish a network of protected areas of the so-called 'Green Belt of Fennoscandia' along the Karelian part of the Russian-Finnish border, altogether covering a third of a million hectares (with over $80 \%$ of that on the Russian side). This 'ecological framework' secures the natural biotic diversity as well as a system of valuable recreational areas (with the promise of tourism development there). There are no analogues for this elsewhere in Russia. D. Sevastiyanov and co-workers underline that the territory of the Ladoga Skerries form a significant part of this 'ecological framework' (2014). On December 28, 2017 a National Park was established there by Decree of the Government of the Russian Federation (Russian Federation... 2017).

Several cross-border tourist routes have also been designated in the region in the context of international projects. Today, the development of cross-border tourist routes is considered a tool by which to invigorate economic activity as well as achieve the conservation, reproduction and promotion of this area's natural, cultural and historical potential (Nenonen \& Stepanova 2018). An example would be the Blue Road international tourist route that runs along historical waterways from Norway via the Northern Ladoga region (along the north coast of Lake Ladoga) all the way to the Arkhangelsk region. Several other cross-border tourist routes are drawing on the experience of the Blue Road, with the Mining Road established and a cross-border gastronomic route being developed. 
In the years 1999-2001, within the framework of a project involving historical, cultural and natural sights along the international Blue Road route in the Republic of Karelia, as implemented under the umbrella of a Project called KASPNET (the Karelian-Atlantic spatial development network), the Ruskeala marble quarry was identified as a site of value from the point of view of its natural and cultural heritage. The quality of services on offer to tourists in this region was thus raised under a project seeking to achieve eco-efficient tourism, as supported by the Karelia ENPI CBC Programme (2012-2014).

The cross-border Mining Road tourist route (Karelia ENPI CBC Programme, 2012-2014) in turn links together geological and mining heritage along the Blue Road. Within the region, the Project encompasses the Kiitelä garnet field (the only deposit with jewelrygrade garnets in Russia), the Pitkyaranta's mines, a Salmi rapakivi granites (Pitkyaranta District), the Ruskeala Mountain Park as well as the North Ladoga Republican Museum (in Sortavala District). A set of GPS-assisted excursions (with audio guides) and 3D virtual excursions of the Ruskeala Mountain Park were produced. The Mining Road project was recognized as one of the Programme's best tourism-oriented projects (Shekov 2015). A new cross-border gastronomic tour will also be elaborated under the Kalitka Project for the development of cross-border gastronomic tourism (Karelia ENI CBC Programme, 20182020).

One of the challenges for development of tourism is that land along a border is subject to restrictions on economic activities and the movement of people (Wieckowski 2009; Stepanova 2016). On January 1st 2018, new rules on entering the border zones of Russia entered into force, such that everyone visiting such a zone needs special permission to do so. In line with border-control procedures, entry into a border zone is possible for Russian citizens if they have a Russian Passport. Foreigners in turn require passes that need to be ordered, though free of charge (Order of the Federal... 2017; The Border service).
Beyond that, visits to protected natural areas in the border zone (e.g. the Iso-ljarvi Nature Reserve in Lahdenpohja District) are regulated by special documents of their own.

\section{Discussion}

The political and socio-economic changes taking place in Russia along with changes in the geopolitical situation of the state on the world stage in the 1990s worked to enhance the contact function of the state border, with an attendant relaxation of the visa regime. These processes have yielded a far-reaching transformation in perceptions of tourism and the role it can play in the development of the local economy in the Russian-Finnish borderland. In the days of the USSR, the border location of the Northern Ladoga region and the Republic of Karelia as a whole (with a capitalist country) combined with the nonacceptance of tourism as an area of economic activity to not fully allow advantage to be taken of this region's unique potential for tourism and recreation. The borderlands in fact have a unique potential for development, but "their functionality was reduced to a minimum, so that it was important for the border regions to acquire tourism functions" (Alexandrova 2012).

From the 1990s onwards, the economic and geographical location of the Northern Ladoga region started to gain in significance, beginning to act as a new factor underpinning socio-economic development in the region on the basis of opportunities the tourism business was able to supply. The findings relevant to the Swedish-Finnish borderland, in which geopolitical changes in the state have turned the "landscape of defence into an open landscape and established new practices in tourism to emerge" (Prokkola 2010) could be applied to the transformation of the Northern Ladoga region in the Russian-Finnish borderland in the circumstances of the changes taking place in the 1990s. According to the border tourism theory, "borders themselves create unique advantages that make borderland an important destination" (Timothy 
et al 2016). The study supports conclusions received from other border regions, in that the influence of political and socio-economic transformations accompanied by changes of border function have had crucial implications for the development of tourism (Więckowski 2009, 2010; Prokkola 2010). The practice as manifested in the region confirms that "with the disappearance of a border's barrier effect" (Więckowski \& Cerić 2016) cross-border mobility intensifies. In the 1990s, a cross-border flow of 'nostalgic' tourists from Finland had a significant role in the development of tourism in the region and in the Republic of Karelia as a whole. The Northern Ladoga (natural and historical) region thus gained a new opportunity to develop, and started to transform from a 'closed' border area into a destination for tourism. Thus, since the 1990s, the border has been a landscape modifier (Timothy et al. 2016) of the Northern Ladoga region in the wider context of the Russian-Finnish borderland.

Tourism began to take shape as a sector of the local economy by generating income for budgets at all levels and creating new jobs. Additional employment opportunities are created for residents as they become more and more involved in rendering tourist services, and thus gain extra income for the family from catering, guiding, the renting of gear, the sale of souvenirs and foodstuffs to tourists, the organization of craft workshops and entertainments based on local historical and cultural traditions, etc. Thus, "by using the social capital of a destination region, tourism could more effectively benefit both regional development and its own economic growth purposes" (Saarinen 2003) - as is confirmed in practice in the region under study.

The modern period of tourism development here has certain common features with the first period in which tourism and recreation in the area developed. Firstly, the major types of tourism in the region are cultural tourism (also with a religious aspect), nature tourism and event tourism. Nature tourism and related activities "have a good potential to provide employment opportunities and well-being to local" communities via both tourism itself and the related economic sectors (Saarinen 2003). A new developing type of tourism in the region entails cross-border shopping (for Finnish travellers), and this has an economic impact on local development in borderlands around the world. "Crossborder shopping is an important reason for tourists to visit the region" and "many of the cross-border tourists visiting the region would not have come without the possibility for shopping" (Makkonen 2016). The development of retail trade and food infrastructure in the region confirms the role of cross-border mobility as an important factor in the development of a borderland, even if a visitor's "stay is of just a few hours' duration" (Więckowski 2010). Today, cross-border tourism (including by Russian tourists going to Finland) is important in terms of the further development of tourism and the local economy more generally. Secondly, active development of infrastructure relating to tourism and transport is taking place.

Nowadays the unique tourist and recreational potential of the Northern Ladoga region (including that arising from its borderland location) is gaining active utilisation as tourism develops. Taking the topicality of the Northern Ladoga region as a prospective tourist destination in the Russian-Finnish borderland into consideration, as well as the significance of full use being made of its unique potential (without damaging the environment), measures to be proposed include:

- enhancement of tourism infrastructure to allow the needs of tourists to be met in full;

- enhancement of infrastructure relating to transport, including of a roadside and waterside character;

- ensuring that unique sites and tourist routes are equally accessible to all categories of visitor, including those with special needs;

- implementation of projects designed to develop tourism in borderlands, and to build cross-border networks of stakeholders; 
- marketing, including the promotion of tourist products of the Northern Ladoga region on the services markets of Russian and the wider world.

A successful example of cross-border cooperation between border regions of Finland and Russia (the Republic of Karelia) is provided by the implementation of tourismoriented projects. Along with the establishment of cross-border protected areas and the placemaking of tourist attractions, these projects help invigorate business activity, with tourism infrastructure developed or improved and new tourism products created. Important for further development of tourism is the fact that "projects aim to promote networking between local tourism actors" (Makkonen et al. 2018). Tourism is an economic activity that "can reinforce territorial cohesion" (Prokkola 2008), while the development of crossborder destinations is considered "part of cross-border region building processes" in the EU (Nilson et al. 2010; Więckowski \& Ceric 2016). In the case of the EU-Russia border, the design and development of crossborder tourist routes (the running through the region of the Mining Road, a gastronomic route, etc.) in the wider context of projects is considered to be (on the one hand) a factor in the conservation, reproduction and promotion of the area's natural, cultural and historical potential, and (on the other) a step towards the establishment of cross-border tourism space.

Analysis of the development of tourism in the region over the study period reveals an upward trend for parameters of key significance to the development of tourism, suggesting it is turning into an efficient business sector, developing dynamically. For instance, the region attracts tourist flows exceeding those to the Kizhi Museum, as a known tourism destination of the Republic of Karelia.

\section{Conclusion}

The research determined that political and socio-economic changes taking place in the 1990s, as accompanied by a new development of the contact function, have brought about a profound transformation in the perception of tourism and its role where the local economy in the Russian-Finnish borderland is concerned. The research explores the transformation of the Northern Ladoga region - the natural and historical region influenced by these changes as a 'closed' border area gives way to a tourism destination (the only case in the Republic of Karelia). The research identifies Sortavala District as the core of the Northern Ladoga destination. The unique natural, historical, and cultural heritage here prevails in the development of tourism and recreation. The borderline location of the region determined by political and socio-economic conditions has been the key factor in the development of tourism, and the research identified three distinct periods in this process. Analysis of tourism development in the region reveals an upward trend in key parameters, suggesting that an efficient and dynamically developing business sector in tourism is now emerging.

\section{Acknowledgments}

The author is grateful for the constructive and helpful comments and suggestions offered by the Reviewers. The paper was prepared as part of the implementation of State Order No. AAAA-A19-119010990088-8 of 19.01.2019 Methodology of system research and management development of the economic, social and cultural space of the northern and border areas of Russia in the context of national security.

\section{Editors' note:}

Unless otherwise stated, the sources of tables and figures are the authors', on the basis of their own research. 


\section{References}

Alexandrova A.Yu., 2012. Political-administrative boundaries: From being a barrier to becoming a tourist resource. Vestnik Moskovskogo universiteta, Ser. 5 Geografija, no. 3, pp. 15-20. [Russian]

Artemyev A.B., Yushko A.A., 2012. Integrated development of Ruskeala Mountain Park. Speleology and spelestology, no. 3, pp. 263-265. [Russian]

Artobolevskij S., 2006. Border territories of the Russian Federation: What the state can and wants. Russian Expert Review, no. 4 (18), pp. 9-11. [Russian]

Björn I., 2015. Border province: The main features of the development of North Karelia after World War II. Studia Humanitatis Borealis, vol. 5, no. 2, pp. 4-16. [Russian]

Bujdoso Z., David L., Varga D., Zhakupov A., Gyurkó Á., Pénzes Já., 2015. Tourism development and cross-border cooperation in the Hungarian-Romanian border region. GeoJournal of Tourism and Geosites, vol. 16, no. 2, pp. 154-164.

Druzhinin P.V., 2005. Development economy of border regions in transition. Petrozavodsk: Karel'skij naučnyj centr Rossijskoj akademii nauk. [Russian]

Eskelinen H., Oksa J., Austin D. (ed.), 1994. Russian Karelia in search of a new role. Joensuu: Karelian institute. University of Joensuu.

From St. Petersburg to the Mountain Park Ruskeala with the new speed train. https://www.russianrail.com/news/from-st-petersburg-to-the-mountain-park-ruskeala-with-the-new-speed-train.html [27 December 2018].

Gromov V.V., 2003. The impact of tourism on the development of the region. Petrozavodsk: Scandinavia. [Russian]

Ivanter D., Shchurov I., Shirokov V., 2002. Hiitola River as a promising object of fishing tourism (the fisheries estimations). Petrozavodsk: Scandinavia.

Izotov A., Laine J., 2013. Constructing (un)familiarity: Role of tourism in identity and region building at the Finnish-Russian border. European Planning studies, vol. 21, no. 1, pp. 93-111. https://doi.org/10.1080/09654313.2012.716241

Jakosuo K., 2011. Russia and the Russian tourist in Finnish tourism strategies - The case of the Karelian region. Procedia - Social and Behavioral Sciences, vol. 24, pp. 1003-1013.

https://doi.org/10.1016/j.sbspro.2011.09.015

Karelia will receive 5 billion for tourism development.

http://www.rusadventures.ru/news/4797.aspx [16 October 2017]. [Russian]

Karelia: guidebook, 2012. Petrozavodsk: Forever.

Karhapää-Puhakka S., Suni J. (ed.), 2014. The attractiveness of rural tourism destinations in the Republic of Karelia and Eastern Finland. Joensuu: University of Eastern Finland.

Kovács I., Nagy G., 2013. Tourism in peripheric regions - The possibilities of thematic routes. Analele Universității din Oradea. Seria Geografie, no. 2, pp. 220-228.

Kropinova E.G., 2014. Project "Crossroads 2.0" in the creation of the crossborder tourism region in the South-Eastern Baltic area. Pskov regionologichesky journal, no. 17, pp. 53-59.

Kurilo A.E., Kurilo M.O., Nemkovich E.G., Stepanova S.V., Chubieva I.V., 2009. Economic and geographical reference book of municipalities of the Republic of Karelia. Petrozavodsk: Institut èkonomiki Karel'skogo naučnogo centra Rossijskoj akademii nauk. [Russian]

Laine J., 2017. Finnish-Russian border mobility and tourism: Localism overruled by geopolitics [in:] D. Hall (ed.) Tourism and geopolitics: Issues and concepts from Central and Eastern Europe, Wallingford: CABI, pp. 178-190. https://doi.org/10.1079/9781780647616.0178

Lintunen P., Hytönen M., Ikonen K., Kivimäki S., 1998. Laatokan pohjoisrannikon kulttuuriympäristö: suomalainen kulttuuriperintö Laatokan pohjoisrannikon maisemissa. Helsinki: Suomen ympäristökeskus. [Finnish]. 
Makkonen T., 2016. Cross-border shopping and tourism destination marketing: The case of Southern Jutland, Denmark. Scandinavian Journal of Hospitality and Tourism, vol. 16, sup. 1, pp. 36-50. https://doi.org/10.1080/15022250.2016.1244506

Makkonen T., Williams A., Weidenfeld A., Kaisto V., 2018. Cross-border knowledge transfer and innovation in the European neighbourhood: Tourism cooperation at the Finnish-Russian border. Tourism management, vol. 68, pp. 140-151. https://doi.org/10.1016/j.tourman.2018.03.008

Matznetter J., 1979. Border and tourism: Fundamental relations [in:] G. Gruber, H. Lamping, W. Lutz, J. Matznetter, K. Vorlaufer (eds.), Tourism and borders: Proceedings of the meeting of the IGU Working group: Geography of tourism and recreation - Frankfurt, pp. 61-73.

Mezhevich N., 2006. Models of cross-border cooperation in Russia: Research experience in municipalities of the Pskov region. Rossijskoe èkspertnoe obozrenie, no. 4(18), pp. 28-30. [Russian]

Mikhailova N., leshko E., Lintunen P. (eds.), 2000. Land use planning, tourism and regional development in the north-west coast of Lake Ladoga and eastern Lake Saimaa area. Petrozavodsk: Karelian Research Center RAS.

Morozova T.V., 2006. Karelian model of transboundary cooperation and development of border local communities. Economics of Contemporary Russia, no. 1, pp. 73-89. [Russian]

Nenonen J.K., Stepanova S.V., 2018. Geological tourism development in the Finnish-Russian borderland: The case of the cross-border geological route "Mining Road". Acta Geoturistica, vol. 9, no. 1, pp. 23-29. https://doi.org/10.1515/agta-2018-0003

Nilson J.H., Eskilsson L., Ek R., 2010. Creating cross-border destinations: Interreg Programmes and regionalization in the Baltic Sea area. Scandinavian Journal of Hospitality and Tourism, vol. 10, no. 2, pp. 153-172. https://doi.org/10.1080/15022250903561978

Nyaupane G.P., Poudel S., Timothy D.J., 2018. Assessing the sustainability of tourism systems:

A social-ecological approach. Tourism Review International, vol. 22, no. 1, pp. 49-66. https://doi.org/10.3727/154427218x15202734130440

Objects of cultural heritage of the Republic of Karelia, http://monuments.karelia.ru/ob-ekty-kul-turnogo-nasledija/statisticheskie-svedenija-po-dislokacii-ob-ektov-kul-turnogo-nasledija-respubliki-karelija/ [15 August 2018]. [Russian]

Order of the Federal Security Service of Russia of August 7, 2017 N 454, "On approval of the rules of the border regime", http://www.consultant.ru/document/cons_doc_LAW_282173/[20 December 2018]. [Russian].

Owl Mountain - the museum in the cliff. Retrieved from http://gorafilina.ru/en_gb [10 December 2019].

Pashkov A.M., 2004. The presentation of Old Finland in the descriptions of Russian travellers and observers from the end of 18th to the beginning of the 20th century. Fennia - International Journal of Geography, vol. 182, no. 1, pp. 13-22.

Potakhin S.B., 2001. Retrospective analysis of tourism development in the Northern and North-Western Ladoga region. Comprehensive geographical studies of Karelian nature protection areas: Program, reports and abstracts of the scientific-practical conference April 25-26, 2000. Petrozavodsk: Karelian State Pedagogical University. [Russian]

Prokkola E.-K., 2008. Resources and barriers in tourism development: Cross-border cooperation, regionalization and destination building at the Finnish-Swedish border. Fennia, vol. 186, no. 1, pp. 31-46.

Prokkola E.-K., 2010. Borders in tourism: The transformation of the Swedish-Finnish border landscape. Current Issues in Tourism, vol. 13, no. 3, pp. 223-238. https://doi.org/10.1080/13683500902990528

Ruskeala Mountain Park. https://ruskeala.ru/ [05 December 2018].

Ruskeala Symphony Music Festival, 2018. Ruskeala Mountain Park, https://ruskeala-symphony.com/en/page/about [20 December 2018].

Russia - Northern Forest Baja will traditionally open the new season in the FIA World Cup for cross-country rallies. https://www.rallyraidnetwork.com/rrn/?view=article\&id=1753:russia-northern- 
forest-baja-will-traditionally-open-the-new-season-in-the-fia-world-cup-for-cross-country-rallies\&catid$=189$ [21 December 2018].

Russian Federation Government Decree On the creation of the National Park Ladoga Skerries on 28.12.2017 no. 1684. The official website of the Ministry of Nature Management and Ecology of the Republic of Karelia,

https://minprirody.karelia.ru/ohrana-okruzhajucshej-sredy/nacional-nyj-park-ladozhskie-shhery/ [20 December 2018]. [Russian]

Saarinen J., 2003. The regional economics of tourism in Northern Finland: The socio-economic implications of recent tourism development and future possibilities for regional development. Scandinavian Journal of Hospitality and Tourism, vol. 3, no. 2, pp. 91-113. https://doi.org/10.1080/15022250310001927

Saarinen J., 2014a. Conflicting limits to growth in sustainable tourism. Current Issues in Tourism, vol. 18, no. 10, pp. 903-904. https://doi.org/10.1080/13683500.2014.972344

Saarinen J., 2014b. Critical sustainability: Setting the limits to growth and responsibility in tourism. Sustainability, vol. 6, no. 11, pp. 1-17. https://doi.org/10.3390/su6010001

Saveljev Yu.V., Tolstoguzov O.V. (ed.), 2008. Regional tourism management. Practice of the Strategy of the Republic of Karelia,. Petrozavodsk: Karelian Research Center RAS. [Russian]

Sevastiyanov D., Colpaert A., Korostelev E., Mulyava O., Shitova L., 2014. Management of tourism and recreation possibilities for the sustainable development of the north-western border region in Russia. Nordia Geographical Publication, vol. 43, no. 1, pp. 27-38.

Severnoe Priladozhie. Wikimedia Foundation, https://ru.wikipedia.org/wiki/Северное_Приладожье [17 July 2018]. [Russian]

Shekov V.A., 2015. Geological, mining and industrial heritage of the Republic of Karelia and Finland. Cross-Border Cooperation Programme project ENPI CBC "Karelia" KA 334 "Mining road". Proceedings of Karelian Research Centre of Russian Academy of Sciences, no. 7, pp. 205-210. [Russian]

Shishkin A.I., Petrova N.V., 2013. Trans-boundary area of rural tourism: Karelia and Finland. Èkonomika i upravlenie, vol. 89, no. 3, pp. 16-20. [Russian]

Shlyamin V.A., 2002. Russia in the Northern Dimension. Petrozavodsk: Izdatel'stvo Petrozavodskogo gosudarstvennogo universiteta. [Russian]

Specially protected natural areas of the Republic of Karelia, 2017. [Russian]

Stepanova S.V., 2012. Tourism as a perspective direction of development of the territory of the Northern and North-Western Ladoga region: A retrospective review [in:] Proceedings of the III All-Russian summer school for young researchers of evolutionary and institutional economics, vol. 1, Petrozavodsk: Izdatel'stvo Petrozavodskogo gosudarstvennogo universiteta, pp. 208-216. [Russian]

Stepanova S.V., 2016. The role of tourism in the development of Russia's northwestern border regions. Baltic Region, vol. 8, no. 3, pp. 109-120. https://doi.org/10.5922/2079-8555-2016-3-9

Stepanova S.V., Shulepov V.I., 2019. Way to assess the development of municipal tourism infrastructure. Journal of Applied Engineering Science, vol. 17, no. 1, pp. 87-92. https://doi.org/10.5937/jaes17-17073

Tammen Maailmankartasto, 1987. Helsinki: Kustannusosakeyhtiö.

The Administrative-Territorial Division of the Republic of Karelia. The Official Karelia. The official web portal of the Republic of Karelia, http://gov.karelia.ru/gov/Regions/admin_e.html [21 December 2018].

The Border Guard in Figures. The Finnish Border Guide, https://www.raja.fi/current_issues/statistics [14 July 2018].

The Border Service of the Federal Security Service of the Russian Federation. The official website, http://www.ps.fsb.ru/smi.htm [08 August 2018].

The border zone in the Republic of Karelia. The Official Karelia. The official web portal of the Republic of Karelia, http://gov.karelia.ru/gov/Power/Office/FSB/frontier.html] [21 December 2018].

The Federal State Statistics Service, The official website, http://www.gks.ru/wps/wcm/connect/rosstat_main/rosstat/ru/ [08 August 2018]. [Russian] 
The Federal Target Program, "The development of domestic and inbound tourism in the Russian Federation during 2011-2018, Russian Federation Government Decree on 02.08.2011 no. 644. [Russian].

The General Scheme of the Distribution of Tourist Objects and Tourist Infrastructure in Republic of Karelia as part of the Scheme of Land-Use Planning in the Republic of Karelia. Tourist zone "Priladozhskaya", 2007. St. Petersburg. [Russian]

The Main Provisions of the Concept of Social and Economic Development of the Republic of Karelia for the period 1999 - 2002 - 2010. http://old.gov.karelia.ru/Leader/Document/concep.html [10 December 2018].

The museums and cultural sights on the international route "Blue Highway" in Republic of Karelia (Russian Federation), 2007. Petrozavodsk.

The second music festival Ruskeala Symphony gathered six thousand spectators, 2018. The Official Karelia. The official web portal of the Republic of Karelia, http://gov.karelia.ru/gov/News/2018/08/0826_01.html [21 December 2018].

Timothy D.J., 2001. Tourism and political boundaries. London: Routledge.

Timothy D.J., Saarinen J., Viken A., 2016. Editorial: tourism issues and international borders in the Nordic region. Scandinavian Journal of Hospitality and Tourism, vol. 16, no. 1, pp. 1-13. https://doi.org/10.1080/15022250.2016.1244504

Unified tourist passport of the Lahdenpohja municipality of the Republic of Karelia, 2016a. Administration of the Lahdenpohja municipality, $20 \mathrm{pp}$. http://www.uverenniy.ru/unificirovannij-turistskij-pasport-lahdenpohskogo-municipaleno.html [20 December 2018]. [Russian]

Unified tourist passport of the Pitkyaranta municipality of the Republic of Karelia, 2016b. Administration of the Pitkyaranta municipality, 19 pp.

http://www.uverenniy.ru/unificirovannij-turistskij-pasport-lahdenpohskogo-municipaleno.html [20 December 2018]. [Russian]

Unified tourist passport of the Republic of Karelia, 2018. Department of Tourism, 209 pp. http://old.gov.karelia.ru/Power/Committee/Sport/unif_turpass2016.pdf [20 December 2018]. [Russian]

Unified tourist passport of the Sortavala municipality of the Republic of Karelia, 2016c. Administration of the Sortavala municipality, $28 \mathrm{pp}$.

http://рк-сортавала.рф/city/ekonomika_rayona/dokumenty_ekonomiki/?ELEMENT_ID=48828

[20 December 2018]. [Russian]

Vodeb K., 2010. Cross-border regions as potential tourist destinations along the Slovene Croatian frontier. Tourism and hospitality management, vol. 16, no. 2, pp. 219-228.

Vodeb K., Nemec Rudež H., 2017. Which attributes are important to tourists in a mature seaside destinations? A case of Opatija in Croatia. Tourism, vol. 65, no. 3, pp. 267-279.

Więckowski M., 2009. Development of the new tourist space in the Polish borderlands [in:] Discussion Papers, Old and New Borderlines /Frontiers/ Margins, Pécs: Centre for regional studies, pp. 89-97.

Więckowski M., 2010. Tourism development in the borderland of Poland. Geographia Polonica, vol. 83, no. 2, pp. 67-81.

Więckowski M., Cerić D., 2016. Evolving tourism on the Baltic Sea coast: perspectives on change in the Polish maritime borderland. Scandinavian Journal of Hospitality and Tourism, vol. 16, no. 1, pp. 98-111. https://doi.org/10.1080/15022250.2016.1244598

Więckowski M., Michniak D., Bednarek-Szczepańska M., Chrenka B., Ira V., Komornicki T., Rosik P., Stępniak M., Szekely V., Śleszyński P., Świątek D., Wiśniewski R., 2014. Road accessibility to tourist destinations of the Polish-Slovak borderland: 2010-2030 prediction and planning. Geographia Polonica, vol. 87, no. 1, pp. 5-26. https://doi.org/10.7163/gpol.2014.1 